\title{
A mérethatás végeselemes vizsgálata az alakítási határgörbék felvételénél
}

\section{Finite element analysis of size effect for forming-limit curves}

\author{
Gál Viktor \\ Miskolci Egyetem Anyagszerkezettani és Anyagtechnológiai Intézet. Miskolc, Magyarország, \\ metgv@uni-miskolc.hu
}

\begin{abstract}
Nowadays, finite element (FE) methods are widely used for the analysis of Body in White parts production. An FE software applies the forming-limit diagram to predict the failure of the sheet metal. There are many new materials for weight reduction; for these new materials, the determination of forming-limit curves (FLC) is important to studying formability issues. There are some cases where the available material for the measurements is not enough or due to some specific measurement parameter, the standard test specimen cannot be used. In these cases, the geometry of the test pieces and the testing equipment should be reduced. In this paper, the material card for DC05 (1.0312) steel was determined based on a tensile test and the Nakajima test. With the material card, simulations were performed to investigate the size effect of the hemispherical punch used for Nakajima forming method. Based on the simulations, the difference between the FLC-s (determined with different equipment) was found to be negligible.
\end{abstract}

Keywords: $F L C$, size effect, forming-limit curve.

\section{Összefoglalás}

Napjainkban az autóipari lemezalkatrészek gyártástechnológiájának tervezése összeforrt a végeselemes modellező szoftverek alkalmazásával. E szoftverek az alakítás során létrejövő határállapotok definiálására az alakítási határgörbét alkalmazzák, így ennek meghatározása elengedhetetlenné vált a folyamatosan fejlesztett új anyagok esetén is. Vannak olyan esetek, amikor a megfelelő mennyiségű alapanyag vagy egyéb különleges vizsgálati körülmények miatt a szabványosított geometriájú szerszámokkal nincs lehetőség a vizsgálat elvégzésére. Ezekben az esetekben a vizsgálóberendezést arányosan redukált méretekkel alkalmazzák. Cikkemben a DC05 (1.0312) anyagminőségen elvégzett szakítóvizsgálat, valamint Nakajima-féle alakíthatósági vizsgálat alapján meghatározott anyagkártya segítségével szimulációkat állítok össze az alakítási diagram felvételéhez szükséges berendezésnél a mérethatás vizsgálatára. A különböző, arányosan csökkentett méretekkel rendelkező berendezésen adott lemezvastagság mellett felvett alakítási határgörbék között az eltérés elhanyagolhatónak adódott.

Kulcsszavak: Nakajima-vizsgálat, mérethatás, alakítási határgörbe.

\section{Bevezetés}

Az autóipar területein folyó fejlesztések irányát az elmúlt években alapvetően a károsanyag-kibocsátás csökkentése határozta meg. Ezek a törekvések a karosszériaelemek gyártásával foglalkozó iparágakban a tömeg csökkentésével realizálódnak. A járművek tömegének csökkentéséhez nem elegendő pusztán a felhasznált anyagok mennyiségét csökkenteni, ezzel egy időben a biztonsági előírások betartása érdekében növelni kell azok szilárdságát is. Ennek köszönhetően napjainkra újabb, nagy szilárdságú anyagok (acélok esetén jellemző példa a nagy szilárdságú Mn-B ötvözésű acél, alumíniumok esetén a 70-es sorozat nagy 
szilárdságú alumíniumötvözetei) és ehhez kapcsolódóan újabb eljárások (press hardening, hot forming and quenching) [1] kidolgozása zajlott le.

Mára mindennapossá vált a lemezalkatrészek számítógéppel segített tervezése, illetve az azok gyártásához tartozó technológiai folyamatok végeselemes modellezése. Ennek megfelelően e szoftverek anyagadatbázisában a már említett új anyagokra, illetve az ahhoz kapcsolódó technológiákra vonatkozó megfelelő információkkal rendelkezniük kell. Ahhoz, hogy a végeselemes modellező szoftverek egy adott termék alakítás közbeni viselkedését helyesen tudják leírni, szükség van az anyag alakváltozási jellemzőinek meghatározására. Ezek a jellemzők lemezalapanyagok esetében a folyásgörbe, amely megmutatja, hogy az anyag hogyan válaszol a képlékeny alakváltozásra, a folyási határfelület, amely meghatározza a rugalmas alakváltozás határát, illetve az alakítási határdiagram (FLD), amely a főalakváltozások függvényében írja le az egyes alakváltozási határállapotokat. Az anyag e három tulajdonságát tartalmazó adatbáziselemeket anyagkártyának nevezzük.

Az anyagtörvények meghatározása nem jelent gondot hagyományos (hideg-) alakítási környezetben. A már említett, korszerü, nagy szilárdságú anyagokhoz azonban jellemzően melegalakítási eljárások tartoznak [2]. Melegalakítási folyamatoknál az anyag viselkedését elsősorban annak hőmérséklet- és alakítási sebességtől való függősége határozza meg, ami egyértelműen indukálja az anyag viselkedését leíró törvényeknek a változását is. E paraméterektől való függés jelentősen megnehezíti az anyagtulajdonságok meghatározását.

Melegalakítás esetén az anyag alakváltozásának megfelelő leírásához szükséges egy kísérleti mátrix felállítása, ahol adott hőmérsékletek mel-

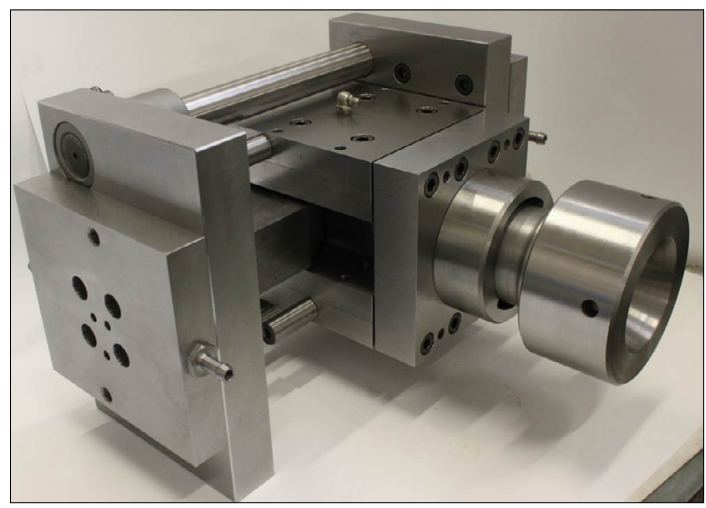

1. ábra. Arányosan csökkentett méretü mérőkészülék alakítási határdiagram meghatározásához lett változó alakváltozási sebességek vannak, illetve adott alakváltozási sebesség mellett eltérő hőmérsékleten végzett kísérletekre is szükség van. A vizsgálatok számának növekedése egyértelművé teszi, hogy egy végeselemes modellezéshez szükséges anyagkártya a hidegalakításhoz képest nagyobb mennyiségű próbatestet igényel. $\mathrm{Az}$ újonnan fejlesztett anyagok esetében nem mindig van lehetőség a vizsgálatokhoz, főleg az alakítási határdiagram felvételénél jellemzően szükséges, nagy mennyiségű, szabványosított méretű próbatest előállítására.

Az alakítási határgörbe hagyományos mérőkészülékkel történő meghatározása jelentős nehézségeket okoz melegalakítási környezetben. Erre az esetre, a már említett kísérleti mátrix hőmérséklettel, illetve alakítási sebességgel kapcsolatos igényeinek teljesítésére, a Miskolci Egyetem Anyagszerkezettani és Anyagtechnológiai Intézetében kifejlesztettek egy olyan vizsgálóberendezést, amely alkalmas az alakítási határdiagramok különböző paraméterekkel való felvételére, és beépíthető az intézetünkben rendelkezésre álló GLEEBLE 3500 típusú termomechanikai szimulátor munkaterébe (1. ábra).

Ez az új készülék az alakítási határdiagram felvételére alkalmas vizsgálatokhoz szükséges szerszámozás egy arányosan kicsinyített megfelelője.

A cikkben bemutatott vizsgálatok alapját az a közismert tény indukálta, hogy az alakítási határgörbék felvételénél az ISO 12004 szabvány [3] alapján legyártott berendezésben elvégzett vizsgálatok esetén, a növekvő lemezvastagság mellett az alakítási határgörbe pozíciója megváltozik a főalakváltozások koordináta-rendszerében. Ez a hatás az alakítási határdiagram jobb oldalán $\left(\varepsilon_{2}>0\right)$ jelentősebb, de általánosan igaz, hogy az alakítási határállapot a főalakváltozás tekintetében pozitív irányban megnő [4] (2. ábra).

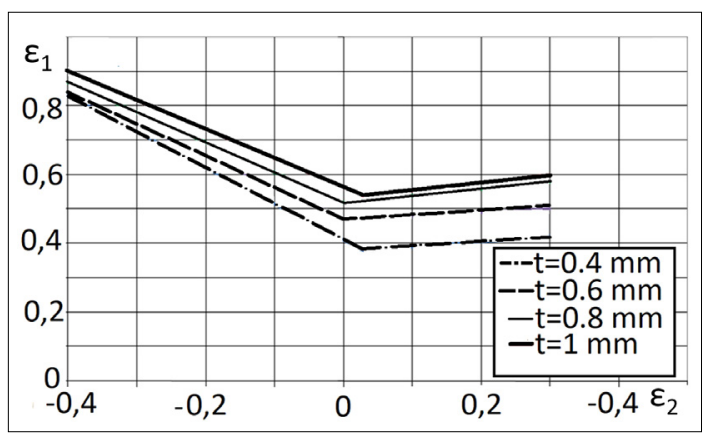

2. ábra. A lemezvastagság hatása az alakitási határgörbére DC05 (1.0312) anyag esetén [4] 
Abban az esetben tehát, ha megváltoztatjuk a lemez vastagságát, ezzel változtatva az alakítóbélyeg- és lemezvastagság-hányadost, az alakítási határgörbék helyzete a főalakváltozások koordináta-rendszerében meg fog változni. Cikkemben további vizsgálatokat végzek a bélyegátmérő/ lemezvastagság-hányados alakítási határgörbére (FLC) gyakorolt hatását vizsgálva, viszont e hányadost az alapanyag vastagságának módosítása helyett a berendezés méreteinek változtatásával fogom befolyásolni.

\section{Az anyagtörvények meghatározása}

Ahogy azt fentebb említettem, a pontos, megbízható végeselemes modellezés alapvető feltétele az alakváltozási jellemzőket pontosan leíró anyagkártya létrehozása. Lemezalkatrészekre vonatkozóan ezt részben szakítóvizsgálattal, illetve Nakajima-vizsgálattal lehet elérni. A vizsgált anyagminőség 1.4828 jelü ausztenites hőálló acél volt $1 \mathrm{~mm}$ lemezvastagsággal, amelyet jellemzően kipufogórendszerekhez alkalmaznak.

Az anyagból lézeres vágással először szakítópróbatestek készültek a hengerlési irányban, arra merőlegesen, illetve azzal $45^{\circ}$-ot bezáróan. A szakítópróbatesteket a Miskolci Egyetem Anyagszerkezettani és Anyagtechnológiai Intézetében található, MTS típusú univerzális elektrohidraulikus berendezéssel szakadásig terheltük. A próbatestek hossz-, illetve szélesség irányú méretváltozás mellett az ezekhez tartozó erőértékeket is folyamatos regisztráltuk. Az erő- és hosszváltozási adatok átszámításával valódi feszültség valódi nyúlás értékeket határoztam meg. A folyásgörbét e pontok képlékeny alakváltozás tartományában található szakasza alapján határoztuk meg.

Az anyag képlékeny alakváltozásának megindulását a $\sigma_{\bar{I}}-\sigma_{I I}$ főfeszültségi síkon egy origó középpontú ellipszis, a folyási határfelület határozza meg. A folyási határfelület az alakváltozás függvényében folyamatosan változik, amely változás a folyási görbe alapján származtatható. A határfelület későbbi, szoftverbe való illesztéséhez a szakítóvizsgálatok eredményei alapján a lemezek hengerlése során létrejövő irányfüggőséget leíró, képlékeny anizotrópiai tényezőt is meghatároztuk.

A végeselemes modellezésnél alkalmazott anyagkártya harmadik része az alakítási határdiagram (FLD), ezen belül pontosabban az alakítási határgörbe (FLC), amely a főalakváltozások rendszerében a töréshez tartozó pontokat összekötő görbe. Az alakítási határgörbe felvételéhez alapvetően öt (3. ábra), de minimum három különböző hídszélességű próbatestre van szükség

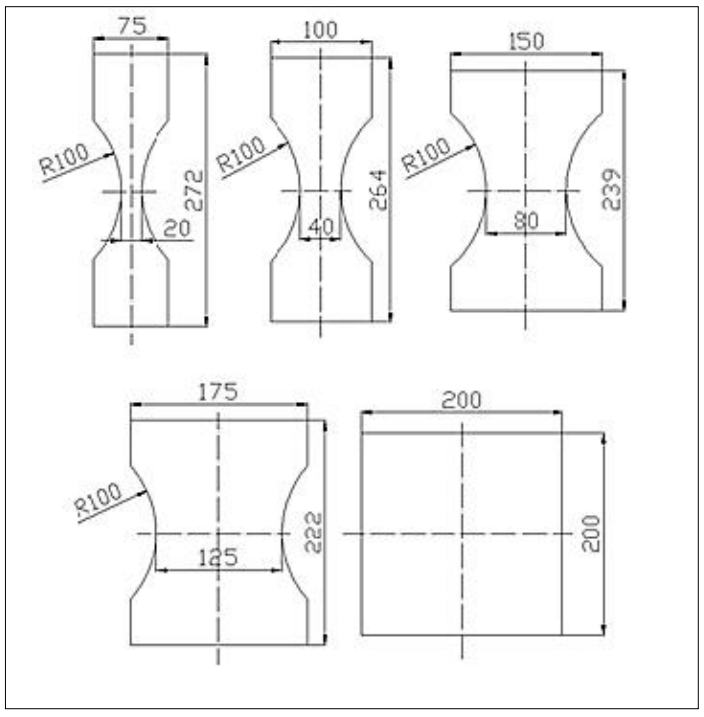

3. ábra. Próbatest-geometriák alakítási határgörbe felvételéhez

a különböző alakváltozási útvonal (alakváltozási történet) megvalósítására. Az eltérő hídszélességű próbatesteket, a szakítóvizsgálatnál említett módon, lézeres vágással munkáltuk ki az 1 mm-es táblalemezből. A vizsgálat során a próbatesteket elmozdulásmentesen rögzítettük egy húzó-, illetve szorítógyưrü közé, majd egy félgömb végződésű nyomófejjel a lemezvastagság irányában egészen szakadásig terheltük. A terhelés során a próbatestek felületére felvitt, $1 \mathrm{~mm}$-es négyzetháló pontjainak az elmozdulását négykamerás optikai mérőrendszer folyamatosan rögzítette.

A pontok egymáshoz képesti elmozdulását a mérőrendszer automatikusan számolja át alakváltozássá, a folyamatos rögzítésnek köszönhetően, így az alakváltozás teljes folyamatáról pontos képet kapunk. A szakadáshoz tartozó alakváltozások alapján határozzuk meg az FLC-görbét.

\section{Végeselemes modellezés}

A fizikai mérések elvégzése után végeselemes modellezés segítségével vizsgáltam meg, hogy milyen hatása van az alakítási határgörbe felvételére a szabványosított méretű próbatesttől és szerszámozástól való eltérésnek. A szimulációkat az AutoForm R8 szoftverben hajtottam végre, ahol első lépésben az anyagkártyát [5], majd a szerszámozást definiáltam.

Az AutoForm biztosítja a lehetőséget arra, hogy az előző fejezetben az egyes alakváltozási jellemzőknél számítással meghatározott pontokat importáljuk a szoftverbe. A folyásgörbe szakító- 
vizsgálattal történő felvételének hátránya, hogy az így kapott pontok az alakváltozásnak csak kis tartományát fedik le. A probléma áthidalására a szoftver a meghatározott pontokra felvett matematikai függvény segítségével hajt végre extrapolációt. Több ismert matematikai modell is rendelkezésre áll a folyásgörbe fizikai pontjainak kiterjesztésére; ebben az esetben a lemezalakítás területén elterjedt, kombinált Swift- és Hockett-Sherby-féle approximációs összefüggést alkalmaztuk, amelynek matematikai alakját az (1) egyenlet mutatja. Ebben $\varepsilon_{p l}$ és $\varepsilon_{0}$ az alakváltozások, $\sigma_{s a t}$ és $\sigma_{i}$ a feszültségek, $a$ és $m$ pedig a keményedési kitevők.

$$
\sigma=(1-\alpha)\left[\mathrm{C} \cdot\left(\varepsilon_{\mathrm{p} 1}+\varepsilon_{0}\right)^{\mathrm{m}}\right]+\alpha\left[\sigma_{\mathrm{sat}}-\left(\sigma_{\mathrm{sat}}-\sigma_{\mathrm{i}}\right) \mathrm{e}^{\mathrm{a} \cdot \varepsilon_{\mathrm{p}}^{\mathrm{p}}}\right]
$$

A folyási határfelület leírására a Hill48-modellt választottuk, amelynek a leírásához szükséges anizotrópia-tényező értékeket a szakítóvizsgálatok eredményei alapján határoztuk meg.

Az anyag képlékeny alakváltozását leíró öszszefüggések meghatározása után a megfelelő szerszámgeometriák importálása következett. A szabványosított szerszámozással készült modellt a 4. ábra szemlélteti. Ezen a $D_{b}$-vel jelölt bélyegátmérő 100 mm. A mérethatás vizsgálatához a bélyegátmérő csökkentésére volt szükség, tehát a 100 mm-es átmérőt először a felére, majd az ötödére csökkentettem úgy, hogy emellett a vizsgálati berendezés minden további mérete is arányosan csökkenjen.

Miután elkészültek a berendezések virtuális modelljei, szükség volt először a szimuláció paramétereinek meghatározására. A súrlódás befolyásolja a próbatesten a szakadás helyét (legfőképpen az alakítási határdiagram pozitív alakváltozásokhoz tartozó tartományában), valamint az alakváltozási útvonalat is [6]. Ahhoz, hogy a valóságot megfelelően tükröző eredményeket kaphassak, a súrlódási tényező beállítását a legnagyobb hídszélességű darabon a szabványos kialakítású szerszámokkal tettem meg, mivel a nagy, érintkező felületek miatt ez ebben az esetben a legmeghatározóbb.

A jellemző súrlódási tényező meghatározása után, az adott beállítások mellett lefuttattam a szimulációkat a további négy hídszélességre is. A kiértékelésnél a fizikai mérés során a szakadásnál mért legnagyobb, vastagság irányú alakváltozást vettem alapul, és ebben a végeselemes csomópontban határoztam meg a főalakváltozásokat.

Az így kapott, szakadáshoz tartozó valódi alakváltozási pontokat az 5. ábra szemlélteti. Ez alap-

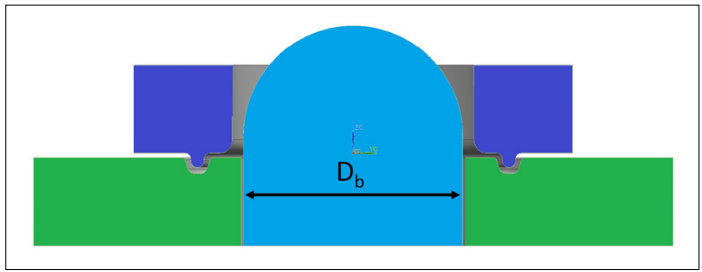

4. ábra. A szabványosított vizsgálóberendezés modellje

A fizikai mérés és a szimuláció eredményei

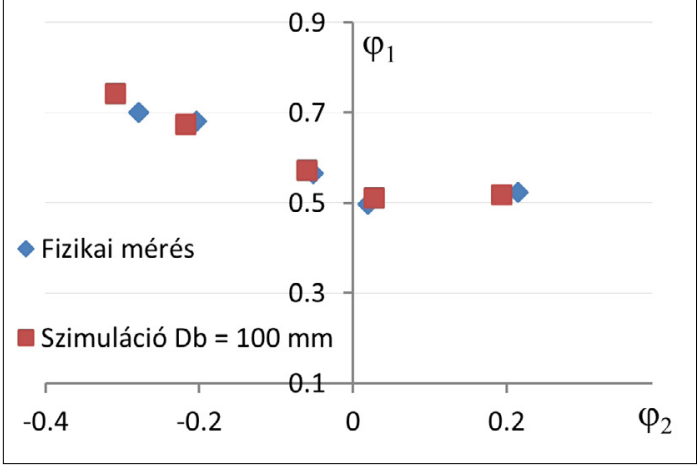

5. ábra. A szimulációval felvett FLC-pontok összevetése a fizikai mérés pontjaival

ján kimondható, hogy a fizikai méréssel, illetve a végeselemes modellezéssel felvett alakítási határgörbe megfelelő korrelációt mutat.

Mivel a 100 mm-es átmérőjű bélyeggel végzett szimulációk a valóságnak megfelelőnek tekinthetők, folytattam a szimulációk összeállítását az arányosan kicsinyített, 50 mm-es, illetve 20 m-es átmérőjű bélyeggel is. Fontosnak tartom megjegyezni továbbá, hogy ezekben az esetekben a 3. ábrán szemléltetett próbatestek méretét állandó lemezvastagság mellett, az adott átmérőnek megfelelően arányosan csökkentettem.

\section{Eredmények és következtetések}

A szimulációk lefuttatása után mind a három átmérő esetében kiértékeltem az egyes próbatestek alakváltozását. Az alakváltozási állapot az egyes hídszélességeknél megegyezik, így a szakadás pontját a 100 mm-es átmérőjü bélyegnél mért lemezvastagság és a vastagság irányú alakváltozás alapján határoztam meg. Az egyes bélyegátmérőkkel felvett alakítási határgörbéket a 6 . ábra szemlélteti.

A 6. ábrán látható FLC-görbék megfelelő korrelációja alapján kijelenthető, hogy a vizsgált bélyegátmérő-tartományban, amennyiben arányosan csökkentjük az egész vizsgálóberendezés mé- 


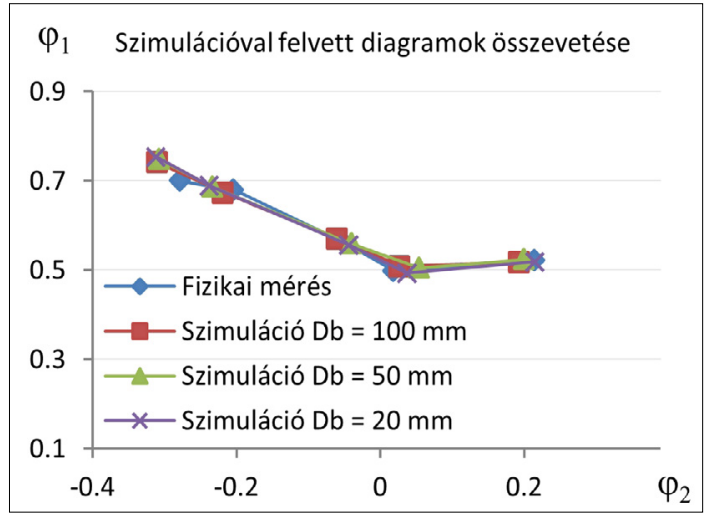

6. ábra. A félgömbvégződésü bélyeg átmérőjének változtatásával létrehozott mérethatás eredményeinek ábrázolása

reteit, az alakítási határdiagramra nincs érdemi hatással a méretek megváltozása adott lemezvastagság mellett.

Az alakítási határgörbék felvételénél tehát nem a berendezés jellemző átmérőjének, illetve a lemezvastagságnak a hányadosa fogja meghatározni az FLC helyét a főalakváltozások függvényében, hanem kizárólag a lemezvastagság lesz rá hatással.

\section{Köszönetnyilvánítás}

Jelen cikkben ismertetett kutatómunka az EFOP3.6.1-16-2016-00011 jelü „Fiatalodó és Megújuló Egyetem - Innovatív Tudásváros - a Miskolci Egye- tem intelligens szakosodást szolgáló intézményi fejlesztése” projekt részeként - a Széchenyi 2020 Program keretében - az Európai Unió támogatásával, az Európai Szociális Alap társfinanszírozásával valósul meg.

\section{Szakirodalmi hivatkozások}

[1] Tisza M., Czinege I.: Comparative study of the application of automotive parts. International Journal of Lightweight Materials and Manufacture, 1/4. (2018) 229-238.

https://doi.org/10.1016/j.ijlmm.2018.09.001

[2] Tisza M.: Nagyszilárdságú bóros mangán acélok autóipari alkalmazása. Anyagmérnöki Tudományok, 39/1. (2016) 68-81.

[3] EN ISO 12004-2 Metallic materials - Sheet and strip - Determination of forming limit curves Part 2: Determination of forming limit curves in laboratory 2006.

[4] Tisza M., Kovács P. Z.: New methods for predicting the formability of sheet metals. Production Processes and Systems, 5/1. (2012) 45-54.

[5] Tisza M., Lukács Zs., Kovács P. Z., Budai D.: Some recent developments in sheet metal forming for production of lightweight automotive parts. $36^{\text {th }}$ IDDRG Conference - Materials Modelling and Testing for Sheet Metal Forming, Munich, Germany, Journal of Physics: Conf. Series 896 (2017) 012087. https://doi.org/10.1088/1742-6596/869/1/012087

[6] Kovács P. Z.: Alakítási határdiagramok elméleti és kísérleti elemzése. PhD-értekezés; Miskolc, 2012. https://doi.org/10.14750/ME.2013.030 